\title{
Diversity of Xylanolytic Bacteria Isolated from Thai Sources
}

\author{
Saowapar Khianngam ${ }^{1}$, Ancharida Akaracharanya ${ }^{2}$, Wonnop Visessanguan ${ }^{3}$, Kwang Kyu Kim ${ }^{4}$, Keun Chul Lee $^{4}$, \\ Jung-Sook Lee ${ }^{4} \&$ Somboon Tanasupawat ${ }^{1}$ \\ ${ }^{1}$ Department of Biochemistry and Microbiology, Faculty of Pharmaceutical Sciences, Chulalongkorn University, \\ Bangkok, Thailand \\ ${ }^{2}$ Department of Microbiology, Faculty of Science, Chulalongkorn University, Bangkok, Thailand \\ ${ }^{3}$ Food Biotechnology Laboratory, National Center for Gentic Engineering and Biotechnology (BIOTEC), \\ Pathumthani, Thailand \\ ${ }^{4}$ Korean Collection for Type Cultures, Biological Resource Center, Korea Research Institute of Bioscience and \\ Biotechnology, Daejeon, Republic of Korea \\ Correspondence: Somboon Tanasupawat, Department of Biochemistry and Microbiology, Faculty of \\ Pharmaceutical Sciences, Chulalongkorn University, Bangkok 10330, Thailand. Tel: 66-2218-8376. E-mail: \\ Somboon.T@chula.ac.th
}

Received: October 16, 2012 Accepted: November 1, 2012 Online Published: November 27, 2012

doi:10.5539/ijb.v5n1p13

URL: http://dx.doi.org/10.5539/ijb.v5n1p13

\begin{abstract}
Twenty-three xylanolytic bacteria were isolated from soils, sediments and buffalo faeces collected in Thailand. They were divided into 10 groups based on the phenotypic and chemotaxonomic characteristics including $16 \mathrm{~S}$ rRNA gene sequence analyses. Eleven isolates were Gram-positive, facultatively anaerobic, spore-forming, rod-shaped bacteria. They contained meso-diaminopimelic in cell wall peptidoglycan. Two isolates (Group IA) were identified as Bacillus subtilis, 4 isolates (Group IB) were B. licheniformis, 2 isolates (Group IC) were $B$. niabensis, one (Group ID) was $B$. nealsonii, and 2 isolates (Group IE) were B. cereus. Seven isolates were Gram-positive, non-spore-forming, rod-shaped bacteria and were identified as Isoptericola variabilis (2 isolates in Group II), as Jonesia denitrificans (2 isolates in Group III), as Microbacterium natoriense (2 isolates in Group IV), and one isolate as Nocardioides simplex (Group V). Five isolates were Gram-negative; facultatively anaerobic, non-spore-forming, rod-shaped bacteria and each of them were identified respectively as Acinetobacter junii (Group VI), Aeromonas enteropelogenes (Group VII), Pseudomonas stutzeri (Group VIII), Stenotrophomonas maltophilia (Group IX) and Zobellella denitrificans (Group X). The isolates produced xylanase activity ranged from 1.03 to $17.65 \pm 0.25 \mathrm{unit} / \mathrm{ml}$.
\end{abstract}

Keywords: Acinetobacter, Aeromonas, Bacillus, Isoptericola, Jonesia, Microbacterium, Nocardioides, Pseudomonas, Stenotrophomonas, Zobellella, xylanolytic bacteria

\section{Introduction}

Xylan, a major component of the hemicelluloses containing heteropolysaccharides, consists of a backbone of $\beta$-1, 4-linked xylopyranose residues with substitutions of $o$-acetyl, arabinosyl and methylglucuronosyl (Chang et al., 2004; Collins et al., 2005; Rawashdeh et al., 2005). The complete hydrolysis of xylan requires the combined action of various enzymes such as endoxylanase and several accessory enzymes to hydrolyse substituted xylan. The endoxylanase attacks internal xylosidic linkages on the backbone and the $\beta$-xylosidase releases xylosyl residues by endwise attack of xylooligosaccharide (Wong et al., 1988). Many microorganisms including bacterial strains of Acidobacterium, Aeromonas, Bacillus, Bacteroides, Cellulomonas, Microbacterium, Paenibacillus, Ruminococcus and Streptomyces, Thermoanaerobacterium and Thermotoga; the yeast strains of Aureobasidium, Cryptococcus and Trichosporon; and the fungal strains of Acrophialophora, Aspergillus, Cephalosporium, Fusarium, Geotrichum, Paecilomyces, Penicilium, Thermomyces and Trichoderma are known to produce different type of xylanases and the nature of the enzymes varies between these different organisms (Rapp \& Wagner, 1986; Beg et al., 2001; Abdelwahed et al., 2011).

In recent years, xylanases have received attractable research interest due to their potential for industrial applications, e.g. pretreatment of pulp to boost the bleaching process (Viikari et al., 1994), pretreatment of forage crops and other lignocellulosic biomasses to improve nutrient utilization, flour improvement for bakery products (Butt et al., 2008), saccharification of hemicellulosic wastes (Gilbert \& Hazlewood, 1993), pulp and fiber processing (Yang et al., 1995), clarification of juices and wines, extraction of plant oils and coffee (Kulkarni et al., 1999; Maheswari \& Chandra, 2000). This work deals with the screening and identification of the 
xylanase-producing bacteria isolated from soils and related materials in Thailand based on their phenotypic and chemotaxonomic characteristics including 16S rRNA gene sequence similarity.

\section{Materials and Methods}

\subsection{Isolation and Screening of Xylanase Activity}

Twenty-three xylanolytic bacteria were isolated from soils, muddy shore sediments, hot spring sediments and buffalo faeces samples collected in Thailand (Table 1), by the spread plate method on XC agar medium as previous report (Kinengam et al., 2007). In this screening step for the thermotolerant strains, the agar plates were incubated at $40^{\circ} \mathrm{C}$ for 2 days. Xylanase-producing capacity of the cultures was detected by using a Congo red overlay method, as reported previously (Teather \& Wood, 1982; Ruijssenaars \& Hartsmans, 2000). Isolates showing xylanase-producing capacity were transferred to $\mathrm{C}$ agar medium. This medium had the same composition of XC medium apart from the omission of the oat spelt xylan. They were assayed for xylanase activity by using dinitrosalicylic acid (DNS) method and using 1\% oat spelt xylan as substrate (Miller, 1959).

\subsection{Identification Methods}

Cells grown on $\mathrm{C}$ agar medium were examined for their morphological and cultural characteristics, including cell shape, colony appearance, endospore formation and pigmentation, after incubation at $37^{\circ} \mathrm{C}$ for 2 days. Physiological and biochemical characterization was performed using the API 20NE and API 50CH (combined with API 50CHB/E medium) strips (bioMérieux), in accordance with the manufacturer's directions. Catalase and oxidase; hydrolysis of casein, DNA, starch, Tween 80, L-tyrosine and urea; the methyl red/Voges-Proskauer (VP) reactions, indole production, citrate utilization and hydrogen sulfide $\left(\mathrm{H}_{2} \mathrm{~S}\right)$ production were determined as described by Barrow and Feltham (1993). Growth at different $\mathrm{pH}(5,6,7,8$ and 9), in 3 and $5 \%(\mathrm{w} / \mathrm{v}) \mathrm{NaCl}$ and at different temperatures $\left(10,15,20,25,30,40,45,50,55\right.$ and $\left.60^{\circ} \mathrm{C}\right)$ was tested by using $\mathrm{C}$ agar medium. All tests were carried out by incubating the cultures at $37^{\circ} \mathrm{C}$, except for investigations into the effect of temperature on growth. Diaminopimelic acid in the cell wall and quinone system were determined as described by Komagata and Suzuki (1987). DNA was prepared by the method of Saito and Miura (1963). DNA base composition was determined by reversed-phase HPLC (Tamaoka \& Komagata, 1984). The 16S rRNA genes of the strains were amplifed by PCR with primers, 27F (5'-AGAGTTTGATCMTGGCTCAG-3') and 1492R (5'-TACCTTGTTACGACTT-3') and PCR products were purified and sequenced as described previously (Tanasupawat et al., 2004). The sequences of strains were aligned with selected sequences obtained from GenBank by using CLUSTAL_X version 1.83 (Thompson et al., 1997). The alignment was edited manually to remove gaps and ambiguous nucleotides prior to the construction of phylogenetic trees. The phylogenetic trees were constructed by using the neighbour-joining (Saitou \& Nei, 1987) method in MEGA4 software (Tamura et al., 2007). The confidence values of branches of the phylogenetic trees were determined using bootstrap analysis (Felsenstein, 1985) based on 1000 resampled datasets.

\section{Results and Discussion}

\subsection{Isolation and Screening of Xylanase Activity}

Twenty-three isolates showed xylanase clear zone with 1.0-12.0 mm in diameter, surrounded their colonies. The xylanase producing bacteria of Group I isolates showed clear zone with 1.7-7.5 $\mathrm{mm}$ in diameter and produced xylanase activity ranged from 1.03 to $3.89 \pm 0.31 \mathrm{unit} / \mathrm{ml}$ while Group II to Group X isolates showed clear zone with $1.0-12.0 \mathrm{~mm}$ in diameter and produced xylanase activity ranged from 1.16 to $17.65 \pm 0.25 \mathrm{unit} / \mathrm{ml}$. It was found that the isolate CR2-1 in Group II was produced biggest clear zone with $12.0 \mathrm{~mm}$ in diameter and had highest xylanase activity $(17.65 \pm 0.25 \mathrm{unit} / \mathrm{ml})$ as shown in Table 1 . In this study, the isolates showed a wide ranges of xylanolytic activity and were better than as reported in the non spore-forming, Gram-positive irregular rods $(0-0.13$ units $/ \mathrm{ml})$ and the isolates of Gram-positive spore-forming rods; the isolates of Gram-negative rods; and isolate of Gram-positive rods/cocci (0-0.17 units/ml) by Kinengam et al. (2007).

\subsection{Identification and Characterization of Isolates}

Twenty-three isolates were divided into ten groups and were identified based on their phenotypic characteristics and the 16S rRNA gene sequence analyses.

Group I contained 11 isolates, TH2-2, P2-2, SK1-3, PJ1-2, SRC2-3, K3-6, PHC3-3, FCN3-4, NS1-1, K1-6A and K1-6B (Table 1). They were Gram-positive, motile rod-shaped (approximate 0.5-2.0 x 1.8-6.0 $\mu \mathrm{m}$ ). Central or subterminal ellipsoidal endospores were observed in swollen sporangia. All isolates showed positive for catalase, growth at $\mathrm{pH} 7-9$, at $25-45^{\circ} \mathrm{C}$, hydrolysis of aesculin and DNA but showed negative for Voges-Proskauer (VP), $\mathrm{H}_{2} \mathrm{~S}$ production, indole production and hydrolysis of Tween 80 and acid production from sorbose. They contained meso-diaminopimelic in cell wall peptidoglycan and menaquinones with seven isoprene units (MK-7). They were divided into Group IA to IE based on their phenotypic characteristics (Table 2) and were clustered within a clade of the genus Bacillus (Figure 1) based on 16S rRNA gene sequence and phylogenetic analyses.

Group IA contained 2 isolates, K3-6 and SRC2-3. Colonies were 3-6 mm in diameter, round, smooth, raise, 
opaque and creamy or white after 2 days of incubation at $37^{\circ} \mathrm{C}$ on $\mathrm{C}$ medium. They grew in $3-5 \% \mathrm{NaCl}$, at $\mathrm{pH}$ $5-9$ and at $25-50^{\circ} \mathrm{C}$ but no growth at 10 and $60^{\circ} \mathrm{C}$. Their differential and variable characteristics were shown in Table 2. On the basis of 16S rRNA gene sequence, isolates K3-6 (926 nt) and SRC2-3 (963 nt) were closely related to $B$. subtilis subsp. subtilis KCTC $3135^{\mathrm{T}}$ (Figure 1) with $100 \%$ sequence similarity. Therefore, they were identified as B. subtilis subsp. subtilis (Nakamura et al., 1999).

Group IB contained 4 isolates, PJ1-2, SK1-3, P2-2 and TH2-2. Colonies were 3-12 mm in diameter, irregular or round, lobate or entire, wrinkled, raise, opaque and creamy or yellow after 2 days of incubation at $37^{\circ} \mathrm{C}$ on $\mathrm{C}$ medium. All isolates grew in $3-5 \% \mathrm{NaCl}$, at $\mathrm{pH} 5-9$ and at $25-45^{\circ} \mathrm{C}$ but no growth at 10 and $60^{\circ} \mathrm{C}$. Their differential and variable characteristics were shown in Table 2. On the basis of $16 \mathrm{~S}$ rRNA gene sequence, the isolates TH2-2 (1,488 nt), P2-2 (971 nt), SK1-3 (927 nt) and PJ1-2 (947 nt) were closely related to $B$. licheniformis KCTC $1918^{\mathrm{T}}$ (Figure 1) with 99.7, 99.2, 99.1 and $99.6 \%$ sequence similarity, respectively. Therefore, they were identified as B. licheniformis (Daffonchio et al., 1998; Palmisano et al., 2001).

Group IC contained 2 isolates, K1-6B and K1-6A. Colonies were 3-5 mm in diameter, irregular, curled, concentric, flat, opaque and creamy or white after 2 days of incubation at $37^{\circ} \mathrm{C}$ on $\mathrm{C}$ medium. They grew in $3-5 \% \mathrm{NaCl}$, at $\mathrm{pH} 7-9$ and at $25-50^{\circ} \mathrm{C}$, but did not grow at $\mathrm{pH} 5-6$, at $10-15,55$ and $60^{\circ} \mathrm{C}$. Their differential and variable characteristics were shown in Table 2. On the basis of $16 \mathrm{~S}$ rRNA gene sequence, the isolates K1-6A (981 nt) and K1-6B (944 nt) were closely related to B. niabensis $4 \mathrm{~T} 19^{\mathrm{T}}$ (Figure 1) with 99.9 and $100 \%$ sequence similarity, respectively. Therefore, they were identified as B. niabensis (Kwon et al., 2007).

Table 1. Location, sample, isolate number, group, xylanase activity and identification of the isolates

\begin{tabular}{|c|c|c|c|c|c|}
\hline $\begin{array}{l}\text { Location } \\
\text { (Province) }\end{array}$ & Sample & Isolate no. & Group & $\begin{array}{l}\text { Xylanase } \\
\text { (unit/ml) }\end{array}$ & Identification \\
\hline Kanchanaburi & Soil & K3-6 & IA & $2.22 \pm 0.35$ & B. subtilis \\
\hline Suratthani & Soil & SRC2-3 & IA & $6.07 \pm 0.55$ & B. subtilis \\
\hline Prachuapkhirikhan & Muddy shore sediment & PJ1-2 & IB & $1.21 \pm 0.16$ & B. licheniformis \\
\hline Samutsongkhram & Soil & SK1-3 & IB & $1.60 \pm 0.18$ & B. licheniformis \\
\hline Phetchaburi & Soil & $\mathrm{P} 2-2$ & IB & $2.89 \pm 0.02$ & B. licheniformis \\
\hline Trat & Soil & TH2-2 & IB & $3.89 \pm 0.31$ & B. licheniformis \\
\hline Kanchanaburi & Soil & K1-6B & IC & $1.22 \pm 0.24$ & B. niabensis \\
\hline Kanchanaburi & Soil & $\mathrm{K} 1-6 \mathrm{~A}$ & IC & $1.49 \pm 0.17$ & B. niabensis \\
\hline Nakhonsithammarat & Soil & NS1-1 & ID & $1.07 \pm 0.03$ & B. nealsonii \\
\hline Phetchaburi & Muddy shore sediment & PHC3-3 & IE & $1.34 \pm 0.02$ & B. cereus \\
\hline Nakhonnayok & Buffalo faeces & FCN3-4 & IE & $1.03 \pm 0.03$ & B. cereus \\
\hline Chiangrai & Hot spring sediment & CR1-2 & II & $17.65 \pm 0.25$ & I. variabilis \\
\hline Chiangrai & Hot spring sediment & CR5-1 & II & $8.10 \pm 0.12$ & I. variabilis \\
\hline Phetchaburi & Muddy shore sediment & PHX2-5 & III & $1.21 \pm 0.16$ & J. denitrificans \\
\hline Nakhonnayok & Buffalo faeces & FXN1-1B & III & $1.16 \pm 0.13$ & J. denitrificans \\
\hline Suratthani & Soil & SRC1-1 & IV & $1.53 \pm 0.03$ & M. natoriense \\
\hline Suratthani & Soil & SRC3-3 & IV & $1.18 \pm 0.05$ & M. natoriense \\
\hline Suratthani & Soil & SRX2-3 & V & $1.52 \pm 0.02$ & N. simplex \\
\hline Suratthani & Soil & SRX2-1 & VI & $1.30 \pm 0.03$ & Ac. junii \\
\hline Suratthani & Soil & SRX2-2 & VII & $1.21 \pm 0.10$ & A.enteropelogenes \\
\hline \multirow[t]{2}{*}{ Phetchaburi } & Muddy shore sediment & PHX3-1 & VIII & $1.28 \pm 0.07$ & P. stutzeri \\
\hline & Muddy shore sediment & PHX2-7 & $\mathrm{X}$ & $9.27 \pm 0.19$ & Z. denitrificans \\
\hline Nakhonnayok & Buffalo faeces & FXN3-1 & IX & $1.28 \pm 0.07$ & St. matophila \\
\hline
\end{tabular}

"One unit of xylanase activity was defined as $1 \mu \mathrm{mol}$ of xylose released per min under the condition assayed.

Group ID contained NS1-1. Colonies were 2-3 mm in diameter, round, concentric, flat, opaque and white after 2 days of incubation at $37^{\circ} \mathrm{C}$ on $\mathrm{C}$ medium. The isolate grew in $3-5 \% \mathrm{NaCl}$, at $\mathrm{pH} 5-7$ and at $15-55^{\circ} \mathrm{C}$ but did not grow at $\mathrm{pH} 8-9$ and at $10,60^{\circ} \mathrm{C}$. The differential and variable characteristics were shown in Table 2 . On the basis of 16S rRNA gene sequence, isolate NS1-1 (1,053 nt) was closely related to B. nealsonii FO-092 ${ }^{\mathrm{T}}$ (Figure 1) with $99.7 \%$ sequence similarity. Therefore, the isolate NS1-1 was identified as B. nealsonii (Venkateswaran et al., 2003).

Group IE contained 2 isolates, PHC3-3 and FCN3-4. Colonies were 2.5-6 mm in diameter, round, smooth or 
curled, flat, opaque and yellow or white after 2 days of incubation at $37^{\circ} \mathrm{C}$ on $\mathrm{C}$ medium. They grew in $3-5 \%$ $\mathrm{NaCl}$, at $\mathrm{pH} 5-9$ and at $10-45^{\circ} \mathrm{C}$, but did not grow at $55-60^{\circ} \mathrm{C}$. Their differential and variable characteristics were shown in Table 2. On the basis of 16S rRNA gene sequence, isolates FCN3-4 (854 nt) and PHC3-3 (895 nt) were closely related to B. cereus IAM $12605^{\mathrm{T}}$ (Figure 1) with 100 and $99.8 \%$ sequence similarity, respectively. Therefore, they were identified as B. cereus (Daffonchio et al., 1998).

Table 2. Differential characteristics of Bacillus isolates in Group I (A to E)

\begin{tabular}{|c|c|c|c|c|c|}
\hline Characteristics & IA & IB & IC & ID & IE \\
\hline Growth at pH $5 \& 6$ & + & + & - & $\mathrm{w}$ & + \\
\hline Growth at $10^{\circ} \mathrm{C}$ & - & - & - & - & + \\
\hline Growth at $15^{\circ} \mathrm{C}$ & $+(-1)$ & - & - & + & + \\
\hline Growth at $50^{\circ} \mathrm{C}$ & + & + & + & + & $-(1 w)$ \\
\hline Growth at $55^{\circ} \mathrm{C}$ & + & + & - & $\mathrm{w}$ & - \\
\hline Oxidase & $+(-1)$ & $+(-1)$ & $+(-1)$ & - & - \\
\hline Citrate utilization & + & $+(-2)$ & - & - & - \\
\hline Methyl red & - & - & - & + & - \\
\hline Nitrate reduction & - & $-(+1)$ & - & - & + \\
\hline L-Arginine hydrolysis & + & + & - & $\mathrm{w}$ & + \\
\hline Casein hydrolysis & + & + & $+(-1)$ & + & + \\
\hline Gelatin hydrolysis & + & + & $+(-1)$ & $\mathrm{w}$ & $+(-1)$ \\
\hline Starch hydrolysis & + & $+(-1)$ & - & - & $-(+1)$ \\
\hline L-Tyrosine hydrolysis & - & - & - & - & $-(+1)$ \\
\hline Urea hydrolysis & + & + & $+(-1)$ & + & + \\
\hline \multicolumn{6}{|l|}{ Acid from } \\
\hline D-Amygdalin & $+(-1)$ & + & $+(-1)$ & & - \\
\hline L-Arabinose & - & + & + & + & - \\
\hline D-Cellobiose & + & $+(-1)$ & $+(-1)$ & + & - \\
\hline D-Fructose & + & $+(-1)$ & - & + & - \\
\hline D-Galactose & - & - & - & + & - \\
\hline D-Glucose & + & $-(+1)$ & - & + & + \\
\hline Gluconate & - & - & - & + & $-(+1)$ \\
\hline Glycerol & + & $-(+1)$ & $-(+1)$ & + & + \\
\hline Inositol & - & - & - & + & - \\
\hline Inulin & $+(-1)$ & - & - & - & - \\
\hline Lactose & - & - & - & + & - \\
\hline D-Maltose & + & + & - & + & + \\
\hline D-Mannitol & + & + & - & + & - \\
\hline D-Mannose & + & $-(+1)$ & - & + & $+(-1)$ \\
\hline D-Melibiose & - & - & - & + & - \\
\hline D-Melezitose & - & - & - & + & - \\
\hline$\alpha$-Glucopyranoside & - & $+(-1)$ & - & + & - \\
\hline Raffinose & - & - & - & + & - \\
\hline L-Rhamnose & - & - & - & + & - \\
\hline D-Ribose & - & $-(+1)$ & - & + & + \\
\hline Salicin & $+(-1)$ & $+(-1)$ & - & + & + \\
\hline Sorbitol & - & - & $+(-1)$ & + & - \\
\hline Sucrose & $+(-1)$ & $+(-1)$ & - & + & $-(+1)$ \\
\hline D-Trehalose & $+(-1)$ & $+(-2)$ & - & + & + \\
\hline D-Xylose & - & $-(w 1)$ & $+(-1)$ & + & - \\
\hline
\end{tabular}

IA, K3-6 \& SRC2-3; IB, PJ1-2, SK1-3, P2-2 \&TH2-2; IC, K1-6A \& K1-6B; ID, NS1-1; IE, FCN3-4 \& PHC3-3. + , positive; -, negative; $\mathrm{w}$, weak positive. Number in parentheses indicates the number of isolate shows positive or negative reaction. 


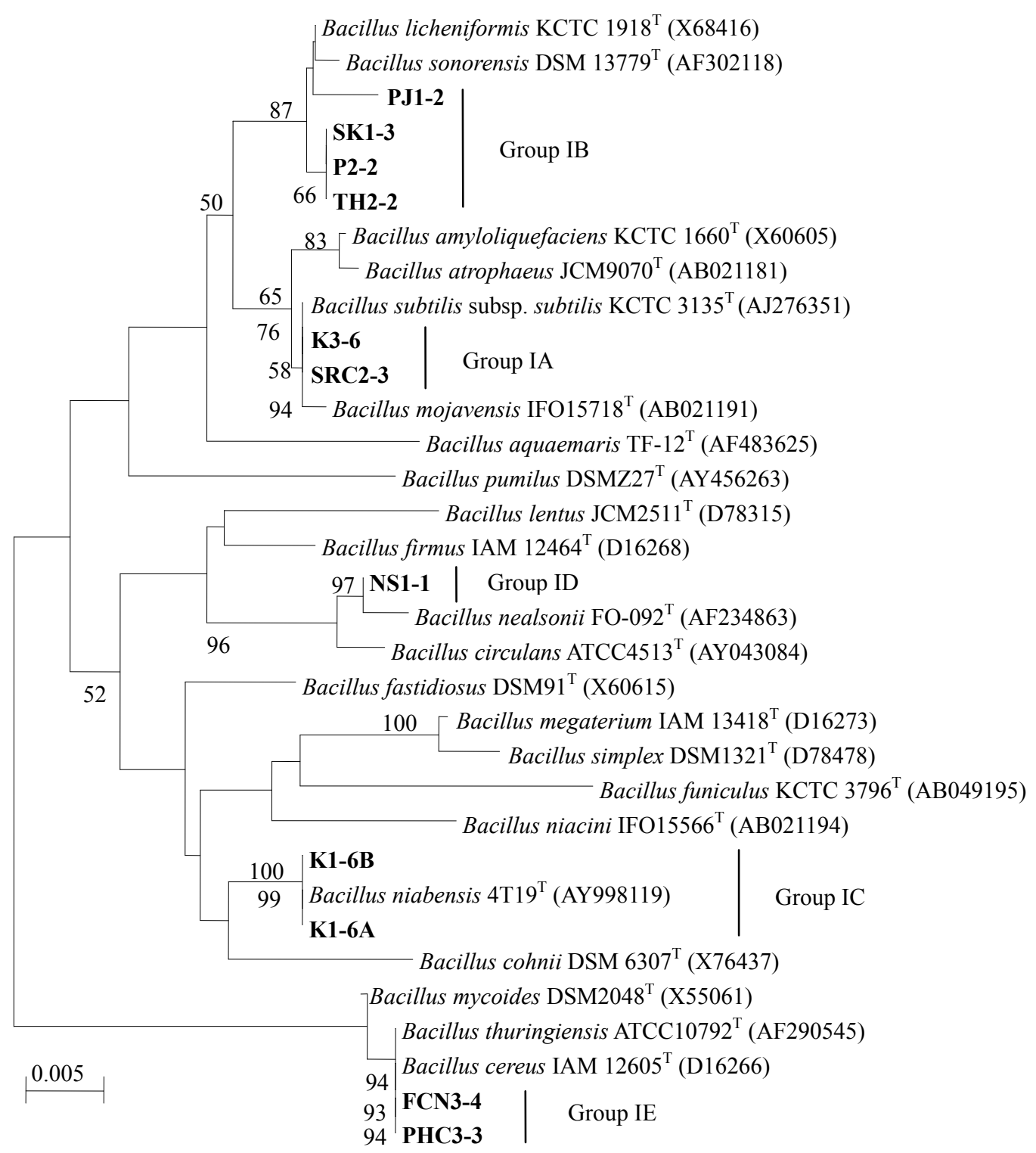

Figure 1. Neighbour-joining tree based on 16S rRNA gene sequences showing the phylogenetic relationships between Bacillus isolates and Bacillus species. Based on 1000 resamplings, bootstrap percentages above $50 \%$ are shown. Bar, 0.005 substitutions per nucleotide position

On the basis of 16S rRNA gene-based phylogenetic tree, as shown in Figures 2 and 3, seven isolates were Gram-positive, non-spore-forming, rod-shaped bacteria and were belonged to Isoptericola (2 isolates in Group II), Jonesia (2 isolates in Group III), Microbacterium (2 isolates in Group IV), and one isolate in Nocardioides (Group V). Five isolates were Gram-negative, facultatively anaerobic, non-spore-forming, rod-shaped bacteria and each of them were belonged respectively to Acinetobacter (Group VI), Aeromonas (Group VII), Pseudomonas (Group VIII), Stenotrophomonas (Group IX) and Zobellella. All 12 isolates showed catalase positive except Group $\mathrm{X}$ isolate. All showed negative for $\mathrm{VP}, \mathrm{H}_{2} \mathrm{~S}$ production, and acid production from D-amygdalin, gluconate, inositol, inulin, L-rhamnose, sorbitol and sorbose. Their differential characteristics are listed below and in Table 3.

Group II contained 2 isolates, CR1-2 and CR5-1. Cells were Gram-positive, rod or coccoid shaped (approximate 0.8-1.0 x 0.8-4.5 $\mu \mathrm{m}$ ), non-spore forming, facultative anaerobic and non-motile. Colonies were $0.5-2.0 \mathrm{~mm}$ in diameter, circular, convex, smooth, opaque and yellow or white after 2 days of incubation at $37^{\circ} \mathrm{C}$ on $\mathrm{C}$ medium. They grew in $3-5 \% \mathrm{NaCl}$, at $\mathrm{pH} 7-9$ (optimally at 7 ) and $25-45^{\circ} \mathrm{C}$ (optimally at $37^{\circ} \mathrm{C}$ ). They did not grow at $\mathrm{pH} 5$ and at $10-15$ and $50-60^{\circ} \mathrm{C}$. Variable characteristics were shown in Table 3. Their phenotypic characteristics are almost the same as I. variabilis $\mathrm{MX}^{\mathrm{T}}$ (data not shown). The isolates CR1-2 (1,006 nt) and CR5-1 (930 nt) were 
closely related to each other with $100 \% 16 \mathrm{~S}$ rRNA gene sequence similarity and to Is. variabilis $\mathrm{MX}^{\mathrm{T}}$ with 99.6\% sequence similarity (Figure 2). The isolate CR1-2 contained MK-9 $\left(\mathrm{H}_{4}\right)$ of menaquinone and $70.0 \mathrm{~mol} \%$ of DNA $\mathrm{G}+\mathrm{C}$ content. Based on the phenotypic properties, chemotaxonomic characteristics and 16S rRNA gene sequence, therefore, they were identified as Isoptericola variabilis (Stackebrandt et al., 2004).

Group III contained 2 isolates, PHX2-5 and FXN1-1B. Cells were Gram positive, rod shaped (approximate 0.5-1.0 x 1.5-2.0 $\mu \mathrm{m}$ ), facultative anaerobic and non-motile. Colonies were 0.5-1.0 $\mathrm{mm}$ in diameter, circular, convex, smooth, translucent and yellow after 2 days of incubation at $37^{\circ} \mathrm{C}$ on $\mathrm{C}$ medium. They grew in $3-5 \%$ $\mathrm{NaCl}$, at $\mathrm{pH} 7-9$ (optimally at 7) and $15-37^{\circ} \mathrm{C}$ (optimally at $30^{\circ} \mathrm{C}$ ). They did not grow at $\mathrm{pH} 5$ and at $50-60^{\circ} \mathrm{C}$.

Their phenotypic characteristics are almost the same as $J$. denitrificans ATCC $14870^{\mathrm{T}}$ (data not shown). The isolates FXN1-1B (922 nt) and PHX2-5 (983 nt) were closely related to each other with 99.8\% 16S rRNA gene sequence similarity and to $J$. denitrificans ATCC $14870^{\mathrm{T}}$ with 99.2 and $99.1 \%$ sequence similarity, respectively (Figure 2). The isolate PHX2-5 contained MK-9 of menaquinone and $58.4 \mathrm{~mol} \%$ of DNA G+C content. Variable characteristics were shown in Table 3. Based on the phenotypic properties, chemotaxonomic characteristics and 16S rRNA gene sequence, isolates FXN1-1B and PHX2-5 were identified as $J$. denitrificans (Rocourt et al., 1987).

Group IV contained 2 isolates, SRC1-1 and SRC3-3. Cells were Gram positive, rod shaped (approximate 0.5-1.0 x 0.6-1.5 $\mu \mathrm{m}$ ), non-spore-forming and non-motile. Colonies were $0.5-2.5 \mathrm{~mm}$ in diameter, circular, convex, smooth, translucent and white after 2 days of incubation at $37^{\circ} \mathrm{C}$ on $\mathrm{C}$ medium. They grew in $3-5 \% \mathrm{NaCl}$, at $\mathrm{pH}$ $5-9$ and $30-45^{\circ} \mathrm{C}$, but no growth at $10-25$ and $50-60^{\circ} \mathrm{C}$. Major menaquinones were MK-11 and MK12. Variable characteristics were shown in Table 3. Their phenotypic and chemotaxonomic characteristics are almost the same as Microbacterium natoriense TNJL143-2 ${ }^{\mathrm{T}}$ (data not shown). The isolates SRC1-1 (1,401 nt) and SRC3-3 (1,397 nt) were closely related to each other with $100 \% 16 \mathrm{~S}$ rRNA gene sequence similarity and to $M$. natoriense TNJL143- $-2^{\mathrm{T}}$ with $99.0 \%$ sequence similarity (Figure 2). Therefore, based on the results mentioned above and phenotypic properties indicated that SRC1-1 and SRC3-3 were identified as M. natoriense (Liu et al., 2005).

Group V contained SRX2-3. Cells were Gram positive, rod or coccoid shaped (approximate 1.0-1.2 x 1.5-6.0 $\mu \mathrm{m})$, motile, non-spore-forming and strictly aerobic. Colonies were $0.7-1.0 \mathrm{~mm}$ in diameter, irregular, flat, smooth, glistening, yellowish-white and opaque after 2 days of incubation at $37^{\circ} \mathrm{C}$ on $\mathrm{C}$ medium. Grew at $\mathrm{pH}$ 6-9 (optimally at 7) and $25-37^{\circ} \mathrm{C}$ (optimally at $30^{\circ} \mathrm{C}$ ), but not growth in $3-5 \% \mathrm{NaCl}$, at pH 5 and at $10-15,45-60^{\circ} \mathrm{C}$. Isolate SRX2-3 contained meso-diaminopimelic in cell wall peptidoglycan. MK-8 $\left(\mathrm{H}_{4}\right)$ was the predominant menaquinone. DNA G+C content was $72.0 \mathrm{~mol} \%$. Their phenotypic and chemotaxonomic characteristics are almost the same as Nocardioides simplex DSM $20130^{\mathrm{T}}$ (data not shown). The isolate SRX2-3 (900 nt) was closely related to $N$. simplex DSM $20130^{\mathrm{T}}$ with $99.3 \%$ sequence similarity (Figure 2). Based on the results mentioned above and phenotypic properties indicated in Table 3, the isolate SRX2-3 was identified as $N$. simplex (Yoon et al., 1997).

Group VI contained SRX2-1. Cells were Gram negative, coccobacilli shaped (approximate 0.4-0.7 x 0.5-0.9 $\mu \mathrm{m}$ ), facultative anaerobic, non-motile. Colonies were $0.5-1.5 \mathrm{~mm}$ in diameter, circular, flat, smooth, yellow and opaque after 2 days of incubation at $37^{\circ} \mathrm{C}$ on $\mathrm{C}$ medium. Grew in $3 \% \mathrm{NaCl}$, at $\mathrm{pH} 5-9$ (optimally at 7) and $10-50^{\circ} \mathrm{C}$ (optimally at $30^{\circ} \mathrm{C}$ ), but not growth in $5 \% \mathrm{NaCl}$ and at $55-60^{\circ} \mathrm{C}$. Isolate SRX2-1 was different in hydrolysis of gelatin, acid production from L-arabinose, glucose, and D-mannose to Acinetobacter junii LMG $998^{\mathrm{T}}$ (data not shown). Predominant ubiquinone of SRX2-1 was Q-9. DNA G+C content was $42.1 \mathrm{~mol} \%$. The isolate SRX2-1 (973 nt) was closely related to A. junii LMG $998^{\mathrm{T}}$ with $99.8 \%$ sequence similarity (Figure 3). Based on the results mentioned above and phenotypic properties indicated in Table 3, the isolate SRX2-1 was identified as A. junii (Bouvet \& Grimont, 1986).

Group VII contained SRX2-2. Cells were Gram negative, rod (approximate 0.4-1.0 x 1.0-4.0 $\mu \mathrm{m}$ ), facultative anaerobic, motile. Colonies were 1-1.6 mm in diameter, irregular, lobate, flat, yellow and opaque after 2 days of incubation at $37^{\circ} \mathrm{C}$ on $\mathrm{C}$ medium. The isolate grew in $3 \% \mathrm{NaCl}$, at $\mathrm{pH} 5-9$ (optimally at 7) and $30-45^{\circ} \mathrm{C}$ (optimally at $30^{\circ} \mathrm{C}$ ), but did not grow in $5 \% \mathrm{NaCl}$, at $10-25$ and $50-60^{\circ} \mathrm{C}$. Predominant ubiquinone of SRX2-2 was Q-8. DNA G+C content was $57.7 \mathrm{~mol} \%$. The isolate SRX2-2 (1,053 nt) was closely related to $A$. enteropelogenes DSM $6394^{\mathrm{T}}$ with $99.4 \%$ sequence similarity (Figure 3). Based on the results mentioned above and phenotypic properties indicated in Table 3, the isolate SRX2-2 was identified as A. enteropelogenes (Collins et al., 1993).

Group VIII contained PHX3-1. Cells were Gram negative, straight rod shaped (approximate 0.3-0.5 x 1.5-2.5 $\mu \mathrm{m}$ ), facultative anaerobic, motile. Colonies were $0.5-1.0 \mathrm{~mm}$ in diameter, circular, raise, smooth, yellowish brown and opaque after 2 days of incubation at $37^{\circ} \mathrm{C}$ on $\mathrm{C}$ medium. The isolate grew in $3-5 \% \mathrm{NaCl}$, at $\mathrm{pH}$ 6-9 
(optimally at 7) and $10-37^{\circ} \mathrm{C}$ (optimally at $30^{\circ} \mathrm{C}$ ), but did not grow at $\mathrm{pH} 5$ and at $45-60^{\circ} \mathrm{C}$. Predominant ubiquinone of PHX3-1 was Q-9. DNA G+C content was 60.6 mol\%. The isolate PHX3-1 (962 nt) was closely related to Ps. stutzeri ATCC $17588^{\mathrm{T}}$ with $99.8 \%$ sequence similarity (Figure 3). Based on the results mentioned above and phenotypic properties indicated in Table 3, the PHX3-1 was identified as P. stutzeri (Döhler et al., 1987).

Group IX contained FXN3-1. Cells were Gram negative, straight rod shaped (approximate 0.4-0.5 x 1.5-2.0 $\mu \mathrm{m}$ ), facultative anaerobic, motile. Colonies were $0.5-1.0 \mathrm{~mm}$ in diameter, circular, flat, smooth, yellowish brown and opaque after 2 days of incubation at $37^{\circ} \mathrm{C}$ on $\mathrm{C}$ medium. The isolate grew in $3-5 \% \mathrm{NaCl}$, at pH 5-9 (optimally at 7) and $10-37^{\circ} \mathrm{C}$ (optimally at $30^{\circ} \mathrm{C}$ ), but did not grow at $45-60^{\circ} \mathrm{C}$. Isolate $\mathrm{FXN} 3-1$ contained Q-8 as predominant ubiquinone and $65.4 \mathrm{~mol} \%$ of DNA G+C content. The isolate FXN3-1 (923 nt) was closely related to St. maltophilia IAM $12423^{\mathrm{T}}$ with $99.4 \%$ sequence similarity (Figure 3). Based on the results mentioned above and phenotypic properties as shown in Table 3, the isolate FXN3-1 was identified as St. maltophilia (Palleroni \& Bradbury, 1993).

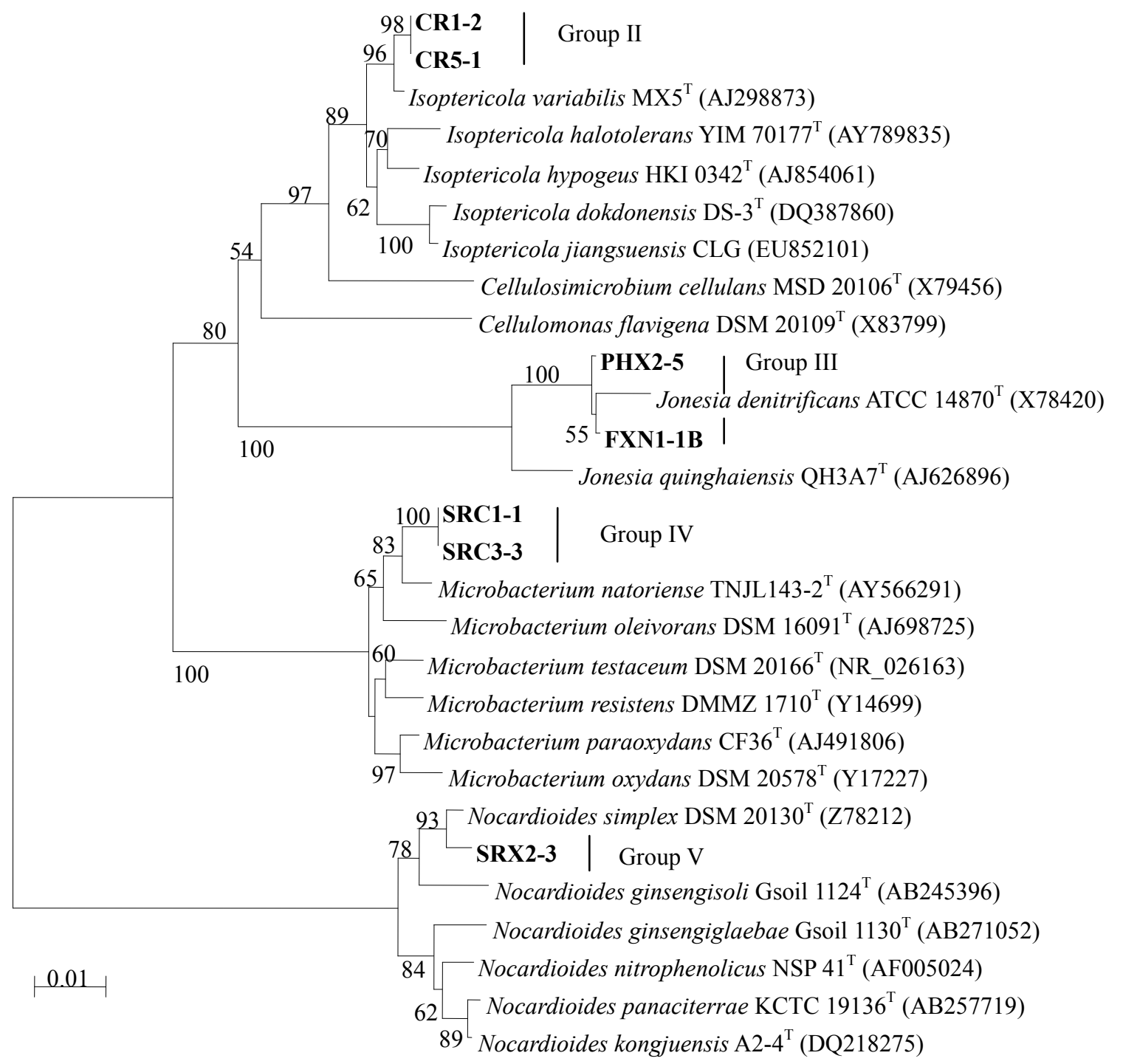

Figure 2. Neighbour-joining tree based on 16S rRNA gene sequences showing the phylogenetic relationships between isolates in Group II to V. Based on 1000 resamplings, bootstrap percentages above 54\% are shown. Bar, 0.01 substitutions per nucleotide position 


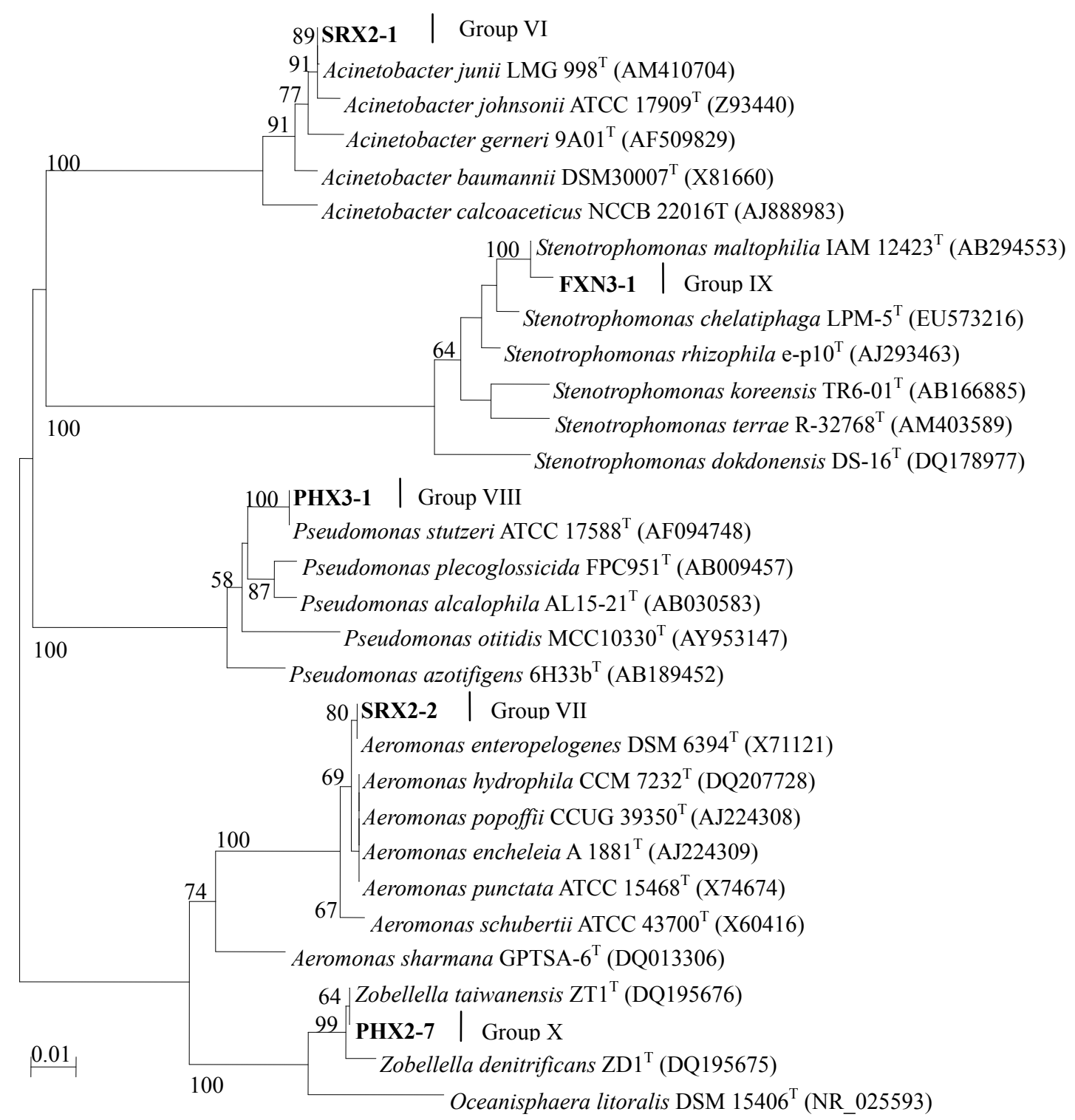

Figure 3. Neighbour-joining tree based on 16S rRNA gene sequences showing the phylogenetic relationships between the isoloates in Group VI to X. Based on 1000 resamplings, bootstrap percentages above $58 \%$ are shown. Bar, 0.01 substitutions per nucleotide position

Group X contained PHX2-7. Cells were Gram negative, rod shaped (approximate 0.6-0.7 x 1.5-2.5 $\mu \mathrm{m}$ ), facultative anaerobic, motile. Colonies were $1.0-4.0 \mathrm{~mm}$ in diameter, circular, raise, smooth, yellow and opaque after 2 days of incubation at $37^{\circ} \mathrm{C}$ on $\mathrm{C}$ medium. The isolate grew in $3-5 \% \mathrm{NaCl}$, at $\mathrm{pH} 5-9$ (optimally at 7) and $25-45^{\circ} \mathrm{C}$ (optimally at $30^{\circ} \mathrm{C}$ ), but did not grow at $10-15$ and $50-60^{\circ} \mathrm{C}$. This isolate showed negative for catalase. It contained Q-8 of ubiquinone and $61.9 \mathrm{~mol} \%$ of DNA G+C content. The isolate PHX2-7 (911 nt) was closely related to $Z$. denitrificans $\mathrm{ZD} 1^{\mathrm{T}}$ and $Z$. taiwanensis $\mathrm{ZT} 1^{\mathrm{T}}$ with $99.2 \%$ and $98.6 \%$ sequence similarity, respectively (Figure 3). Based on the results mentioned above and phenotypic properties indicated in Table 3, the isolate PHX2-7 was identified as Z. denitrificans (Lin \& Shieh, 2006).

Recently, Kinengam et al. (2007) reports that the isolates of Microbacterium barkeri, Bacillus niabensis, B. funiculus, B. megaterium, Pseudoxanthomonas suwonensis, Cupriavidus gilardii, and Rhodococcus rhodochrous strains isolated from soil samples collected in Nan Province, Thailand could produce xylanase. They are found to be diverse species. M. barkeri strain is found in soils collected in Viengsa district while M. barkeri, B. niabensis, B. funiculus, B. megaterium, Px. suwonensis, C. gilardii, and R. rhodochrous strains are distributed in soils samples collected in Muang district. However, in this study, the xylanolytic bacteria, B. subtilis, B. niabensis and 
B. nealsonii isolates are found in soils and B. licheniformis isolates are distributed in soil and muddy shore sediment while $B$. cereus isolates are found in muddy shore sediment and buffalo faeces. In addition, the xylanolytic bacteria of $I$. variabilis from hot spring sediment, $J$. denitrificans, M. natoriense, $N$. simplex, Ac. Junii, A. enteropelogenes, P. stutzeri, St. matophila and Z. denitrificans from soils, muddy shore sediment and buffalo faeces are firstly isolated.

Table 3. Differential characteristics of the isolates in Group II to Group X

\begin{tabular}{|c|c|c|c|c|c|c|c|c|c|}
\hline Characteristics & II & III & IV & $\mathrm{V}$ & VI & VII & VIII & IX & $\mathrm{X}$ \\
\hline Growth in $3 \% \mathrm{NaCl}$ & + & + & + & - & + & + & + & - & + \\
\hline Growth in $5 \% \mathrm{NaCl}$ & + & + & + & - & - & - & + & + & + \\
\hline Growth at pH 5 & - & - & + & - & + & + & - & + & $\mathrm{w}$ \\
\hline Growth at pH 6 & $+(-1)$ & $\mathrm{w}(-1)$ & + & + & + & + & + & + & $\mathrm{w}$ \\
\hline Growth at $10^{\circ} \mathrm{C}$ & - & $+(-1)$ & - & - & + & - & + & + & - \\
\hline Growth at $15^{\circ} \mathrm{C}$ & - & $+(-1)$ & - & - & + & - & + & + & - \\
\hline Growth at $25^{\circ} \mathrm{C}$ & + & + & - & + & + & - & + & + & + \\
\hline Growth at $45^{\circ} \mathrm{C}$ & + & + & + & - & + & + & - & - & + \\
\hline Growth at $50^{\circ} \mathrm{C}$ & - & - & - & - & + & - & - & - & - \\
\hline Oxidase & $\mathrm{w}(-1)$ & $\mathrm{w}(-1)$ & - & - & - & + & + & - & + \\
\hline Citrate utilization & - & - & $\mathrm{w}(-1)$ & - & + & - & + & + & + \\
\hline Indole production & - & - & - & - & - & + & - & - & - \\
\hline Methyl red & - & + & - & - & - & + & - & - & + \\
\hline Nitrate reduction & $+(-1)$ & + & - & - & - & - & - & - & - \\
\hline L-Arginine hydrolysis & + & - & + & + & + & + & + & + & + \\
\hline Casein hydrolysis & + & $+(-1)$ & $\mathrm{w}(-1)$ & + & + & + & - & + & - \\
\hline DNA hydrolysis & + & $+(-1)$ & + & + & + & + & - & + & - \\
\hline Gelatin hydrolysis & + & $\mathrm{w}(-1)$ & $\mathrm{w}$ & + & + & + & - & - & - \\
\hline Starch hydrolysis & + & + & + & - & - & + & + & - & $\mathrm{w}$ \\
\hline L-Tyrosine hydrolysis & $+(-1)$ & - & + & - & + & + & + & + & + \\
\hline Tween 80 hydrolysis & $+(-1)$ & - & - & + & - & - & - & - & - \\
\hline Urea hydrolysis & + & - & + & + & + & + & + & + & + \\
\hline \multicolumn{10}{|l|}{ Acid from } \\
\hline L-Arabinose & - & $+(-1)$ & - & + & $\mathrm{w}$ & $\mathrm{w}$ & - & - & - \\
\hline D-Cellobiose & $\mathrm{w}(-1)$ & $+(-1)$ & + & - & - & $+(-1)$ & - & - & - \\
\hline D-Fructose & $+(-1)$ & $+(-1)$ & + & - & + & + & - & - & + \\
\hline D-Galactose & - & $+(-1)$ & + & - & + & + & - & - & + \\
\hline D-Glucose & - & $+(-1)$ & $+(-1)$ & - & + & + & - & - & + \\
\hline Glycerol & - & - & - & - & + & + & + & - & + \\
\hline Lactose & - & $+(-1)$ & - & - & - & + & - & - & - \\
\hline D-Maltose & - & $+(-1)$ & $+(-1)$ & - & + & + & - & - & + \\
\hline D-Mannitol & - & - & - & - & + & + & - & - & + \\
\hline D-Mannose & - & + & + & - & + & + & - & - & - \\
\hline D-Melibiose & - & $+(-1)$ & + & - & - & - & - & - & + \\
\hline D-Melezitose & - & - & $\mathrm{w}(-1)$ & - & - & - & - & - & + \\
\hline$\alpha$-Glucopyranoside & - & - & $+(-1)$ & - & - & - & - & - & + \\
\hline Raffinose & - & - & - & - & - & - & - & - & + \\
\hline D-Ribose & - & $+(-1)$ & - & - & - & - & - & - & - \\
\hline Salicin & - & + & - & - & + & + & - & - & - \\
\hline Sucrose & $+(-1)$ & $+(-1)$ & + & - & + & + & - & - & + \\
\hline D-Trehalose & $\mathrm{w}(-1)$ & - & - & - & + & + & - & - & + \\
\hline D-Xylose & - & + & $\mathrm{w}(-1)$ & - & - & - & - & - & - \\
\hline
\end{tabular}

II, CR1-2 \& CR5-1; III, PHX2-5 \& FXN1-1B; IV, SRC1-1 \& SRC3-3; V, SRX2-3; VI, SRX2-1 ; VII, SRX2-2; VIII, PHX3-1; IX, FXN3-1; X, PHX2-7. +, positive; -, negative; w, weakly positive. Number in parentheses indicates the number of isolate shows positive or negative reaction.

\section{Conclusion}

The xylanolytic bacteria isolated from various samples collected in Thailand were identified based on the 
analysis of $16 \mathrm{~S}$ rRNA gene sequence. B. subtilis, B. niabensis and B. nealsonii isolates were found in soils. $B$. licheniformis isolates were distributed in soil and muddy shore sediment and $B$. cereus isolates were found in muddy shore sediment and buffalo faeces. This study, we reported the new finding of the xylanolytic bacteria of I. variabilis from hot spring sediment, J. denitrificans, M. natoriense, $N$. simplex, Ac. junii, A. enteropelogenes, P. stutzeri, St. matophila and Z. denitrificans from soils, muddy shore sediment and buffalo faeces. These isolates are the most likely source of enzymes and constitute a heterogeneous group of xylanase producing bacteria belonging to different genera. The isolated bacteria that be able to produce extracellular enzymes will provide the possibility to have optimal activities at different temperature and $\mathrm{pH}$. Thus, the applications of the isolates are required for further study.

\section{Acknowledgements}

The scholarship from the Royal Golden Jubilee Ph. D. Program (2007) to S. K. and a grant from KRIBB Research Initiative Program are gratefully acknowledged.

\section{References}

Abdelwahed, N. A. M., El-Naggar, N. El-A., \& Saber, W. I. A. (2011). Factors and correlations controlling cellulose free xylanase production by Streptomyces Halstedii NRRL B-1238 in submerged culture. Australian Journal of Basic and Applied Sciences, 5(10), 45-53. Retrieved from http://www.ajbasweb.com/ajbas/2011/October-2011/45-53.pdf

Barrow, G. I., \& Feltham, R. K. A. (1993). Cowan and Steel's manual for the identification of medical bacteria $\left(3^{\text {rd }}\right.$ ed, p. 331), Cambridge; New York: Cambridge University Press.

Beg, Q. K., Kapoor, M., Mahajan, L., \& Hoondal, G. S. (2001). Microbial xylanases and their industrial applications: a review. Applied Microbiology and Biotechnology, 56, 326-328. http://dx.doi.org/10.1007/s002530100704

Bouvet, P. J. M., \& Grimont, P. A. D. (1986). Taxonomy of the genus Acinetobacter with the recognition of Acinetobacter baumannii sp. nov., Acinetobacter haemolyticus sp. nov., Acinetobacter johnsonii sp. nov., and Acinetobacter junii sp. nov. and emended descriptions of Acinetobacter calcoaceticus and Acinetobacter lwoffii. International Journal of Systematic Bacteriology, 36, 228-240. http://dx.doi.org/10.1099/00207713-36-2-228

Butt, M. S., Nadeem, M. T., Ahmad, Z., \& Sultan, M. T. (2008). Xylanases and their applications in baking industry. Food Technology and Biotechnology, 46(1), 22-31. Retrieved from http://hrcak.srce.hr/index.php?show=clanak\&id_clanak_jezik=34864

Chang, P., Tsai, W. S., Tsai, C. L., \& Tseng, M. J. (2004). Cloning and characterization of two thermostable xylanases from an alkaliphilic Bacillus firmus. Biochemical and Biophysical Research Communications, 319, 1017-1025. http://dx.doi.org/10.1016/j.bbrc.2004.05.078

Collins, M. D., Martinez-Murcia, A. J., \& Cai, J. (1993). Aeromonas enteropelogenes and Aeromonas ichthiosmia are identical to Aeromonas trota and Aeromonas veronii, respectively, as revealed by small-subunit rRNA sequence snalysis. International Journal of Systematic Bacteriology, 43, 855-856. http://dx.doi.org/10.1099/00207713-43-4-855

Collins, T., Gerday, C., \& Feller, G. (2005). Xylanases, xylanases families and extremophilic xylanases. FEMS Microbiology Reviews, 29, 3-23. http://dx.doi.org/10.1016/j.femsre.2004.06.005

Daffonchio, D., Borin, S., Frova, G., Manachini, P. L., \& Sorlini, C. (1998). PCR fingerprinting of whole genomes, the spacers between the 16S and 23S rRNA genes and of intergenic tRNA gene regions reveal a different intraspecific genomic variability of Bacillus cereus and Bacillus licheniformis. International Journal of Systematic Bacteriology, 48, 107-116. http://dx.doi.org/ 10.1099/00207713-48-3-1081

Döhler, K., Huss, V. A. R., \& Zumft, W. G. (1987). Transfer of Pseudomonas perfectomarina Baumann, Bowditch, Baumann, and Beaman 1983 to Pseudomonas stutzeri (Lehmann and Neumann 1896) Sidjerius 1946. International Journal of Systematic Bacteriology, 37, 1-3. http://dx.doi.org/10.1099/00207713-37-1-1

Felsenstein, J. (1985). Confidence limits on phylogenies: an approach using the bootstrap. Evolution, 39, 783-791.

Gilbert, H. J., \& Hazlewood, G. P. (1993). Bacterial cellulases and xylanases. Journal of General Microbiology, 139, 187-194. http://mic.sgmjournals.org/content/139/2/187.short

Kinegam, S., Tanasupawat, S., \& Akaracharanya, A. (2007). Screening and identification of producing 
xylanase-bacteria from Thai soils. Journal of General and Applied Microbiology, 53, 57-65. Retrieved from http://www.jstage.jst.go.jp/article/jgam/53/1/53_1_57

Komagata, K., \& Suzuki, K. (1987). Lipid and cell-wall analysis in bacterial systematics. Methods in Microbiology, 19, 161-203. http://dx.doi.org/10.1016/S0580-9517(08)70410-0

Kulkarni, N., Shendye, A., \& Rrao, M. (1999). Molecular and biotechnological aspects of xylanases. FEMS Microbiology Reviews, 23, 411-456. http://dx.doi.org/ 10.1111/j.1574-6976.1999.tb00407.x

Kwon, S. W., Lee, S. Y., Kim, B. Y., Weon, H. Y., Kim, J. B., Go, S. J., \& Lee, G. B. (2007). Bacillus niabensis sp. nov., isolated from cotton-waste composts for mushroom cultivation. International Journal of Systematic and Evolutionary Microbiology, 57, 1909-1913. http://dx.doi.org/10.1099/ijs.0.64178-0

Lin, Y. T., \& Shieh, W. Y. (2006). Zobellella denitrificans gen. nov., sp. nov. and Zobellella taiwanensis sp. nov., denitrifying bacteria capable of fermentative metabolism. International Journal of Systematic and Evolutionary Microbiology, 56, 1209-1215. http://dx.doi.org/10.1099/ijs.0.64121-0

Liu, J., Nakayama, T., Hemmi, H., Asano, Y., Tsuruoka, N., Shimomura, K., ... Nishino, T. (2005). Microbacterium natoriense sp. nov., a novel D-aminoacylase-producing bacterium isolated from soil in Natori, Japan. International Journal of Systematic and Evolutionary Microbiology, 55, 661-665. http://dx.doi.org/10.1099/ijs.0.63265-0

Maheswari, M. U., \& Chandra, T. S. (2000). Production and potential applications of a xylanase from a new strain. World Journal of Microbiology \& Biotechnology, 16, 257-263. http://www.springerlink.com/content/u31u4v18061v666q

Miller, G. L. (1959). Use of dinitrosalycylic acid reagent for determination of reducing sugar. Anal. Chem., 31, 538-542.

Nakamura, L. K., Roberts, M. S., \& Cohan, F. M. (1999). Relationship of Bacillus subtilis clades associated with strains 168 and W23: a proposal for Bacillus subtilis subsp. subtilis subsp. nov. and Bacillus subtilis subsp. spizizenii subsp. nov. International Journal of Systematic Bacteriology, 49, 1211-1215. http://dx.doi.org/10.1099/00207713-49-3-1211

Palleroni, N. J., \& Bradbury, J. F. (1993). Stenotrophomonas, a new bacterial genus for Xanthomonas maltophilia (Hugh 1980) Swings et al. 1983. International Journal of Systematic Bacteriology, 43, 606-609. http://dx.doi.org/10.1099/00207713-43-3-606

Palmisano, M. M., Nakamura, L. K., Duncan, K. E., Istock, C. A., \& Cohan, F. M. (2001). Bacillus sonorensis sp. nov., a close relative of Bacillus licheniformis, isolated from soil in the Sonoran Desert, Arizona. International Journal of Systematic and Evolutionary Microbiology, 51, 1671-1679. http://dx.doi.org/10.1099/00207713-51-5-1671

Rapp, P., \& Wagner, F. (1986). Production and Properties of xylan-degrading enzymes from Cellulomonas uda. Applied and Environmental Microbiology, 51, 746-752. Retrieved from http://aem.asm.org/content/51/4/746

Rawashdeh, R., Saadoun, I., \& Mahasneh, A. (2005). Effect of cultural conditions on xylanase production by Streptomyces sp. (strain Ib 24D) and its potential to utilize tomato pomace. African Journal of Biotechnology, 4, 251-255. Retrieved from http://www.ajol.info/index.php/ajb/article/view/15089

Rocourt, J., Wehmeyer, U., \& Stackebrandt, E. (1987). Transfer of Listeria denitrificans to a new genus, Jonesia gen. nov., as Jonesia denitrificans comb. nov. International Journal of Systematic Bacteriology, 37, 266-270. http://dx.doi.org/10.1099/00207713-37-3-266

Ruijssenaars, H. J., \& Hartsmans, S. (2001). Plate screening methods for the detection of polysaccharase producing microorganisms. Appied Microbiology and Biotechnology, 55, 143-149. http://dx.doi.org/10.1007/s002530000477

Saito, H., \& Miura, K. (1963). Preparation of transforming deoxyribonucleic acid by phenol treatment. Biochimica et Biophysicca Acta, 72, 619-629. http://dx.doi.org/10.1016/0926-6550 (63) 90386-4

Saitou, N., \& Nei, M. (1987). The neighboring-joining method: a new method for reconstructing phylogenetic trees. Molecular Biology and Evolution, 4, 406-425.

Stackebrandt, E., Schumann, P., \& Cui, X. L. (2004). Reclassification of Cellulosimicrobium variabile Bakalidou et al. 2002 as Isoptericola variabilis gen. nov., comb. nov. International Journal of Systematic and Evolutionary Microbiology, 54, 685-688. http://dx.doi.org/10.1099/ijs.0.02878-0 
Tamaoka, J., \& Komagata, K. (1984). Determination of DNA base composition by reversed-phase high-performance liquid chromatography. FEMS Microbiolgy Letters, 25, 125-128. http://dx.doi.org/10.1111/j.1574-6968.1984.tb01388.x

Tamura, K., Dudley, J., Nei, M., \& Kumar, S. (2007). MEGA 4: Molecular evolutionary genetics analysis (MEGA) software version 4.0. Molecular Biological Evolution, 24, 1596-1599. http://dx.doi.org/10.1093/molbev/msm092

Tanasupawat, S., Thawai, C., Yukphan, P., Moonmangmee, D., Itoh, T., Adachi, O., \& Yamada, Y. (2004). Gluconobacter thailandicus sp. nov., an acetic acid bacterium in the $\alpha$-proteobacteria. Journal of General and Applied Microbiology, 50, 159-167. http://dx.doi.org/10.2323/jgam.50.159

Teather, R. M., \& Wood, P. J. (1982). Use of Congo red polysaccharide interaction in enumeration of cellulolytic bacteria from bovine rumen. Applied and Environmental Microbiology, 43, 777-780. Retrieved from http://aem.asm.org/content/43/4/777

Teng, J. L. L., Woo, P. C. Y., Leung, K. W., Lau, S. K. P., Wong, M. K. M., \& Yuen, K. Y. (2003). Pseudobacteraemia in a patient with neutropenic fever caused by a novel paenibacillus species: Paenibacillus hongkongensis sp. nov. Molecular Pathology, 56(1), 29-35. Retrieved from http://www.ncbi.nlm.nih.gov/pmc/articles/PMC1187286/

Thompson, J. D., Gibson, T. J., Plewniak, F., Jeanmougin, F., \& Higgins, D. G. (1997). The CLUSTAL_X windows interface: flexible strategies for multiple sequence alignment aided by quality analysis tools. Nucleic Acids Research, 25, 4876-4882. http://dx.doi.org/10.1093/nar/25.24.4876

Venkateswaran, K., Kempf, M., Chen, F., Satomi, M., Nicholson, W., \& Kern, R. (2003). Bacillus nealsonii sp. nov., isolated from a spacecraft-assembly facility, whose spores are $\gamma$-radiation resistant. International Journal of Systematic and Evolutionary Microbiology, 53, 165-172. http://dx.doi.org/10.1099/ijs.0.02311-0

Viikari, L., Kantelinen, A., Sundquist, J., \& Linko, M. (1994). Xylanases in bleaching: from idea to theindustry. FEMS Microbiology Reviews, 13, 335-350. http://dx.doi.org/ 10.1111/j.1574-6976.1994.tb00053.x.

Wong, K. K. Y., Tan, L. U. L., \& Saddler, J. N. (1988). Multiplicity of $\beta-1,4$-xylanase in microorganisms: functions and applications. Microbiology and Molecular Biology Reviews, 52(3), 305-317. Retrieved from $\mathrm{http}: / / \mathrm{mmbr}$.asm.org/content $/ 52 / 3 / 305$.citation

Yoon, J. H., Lee, J. S., Shin, Y. K., Park, Y. H., \& Lee, S. T. (1997). Reclassification of Nocardioides simplex ATCC 13260, ATCC 19565, and ATCC 19566 as Rhodococcus erythropolis. International Journal of Systematic Bacteriology, 47, 904-907. http://dx.doi.org/10.1099/00207713-47-3-904 